\title{
Marc Hertogh, Nobody's Law, Legal Consciousness and Legal Alienation in Everyday Life
}

\author{
Irawan Sewandono
}

Marc Hertogh, Nobody's Law, Legal Consciousness and Legal Alienation in Everyday Life (Londen: Macmillan) 2018, ISBN 978-1-137-60397-5, 215 p.

Hertogh zet zich af tegen de gangbare kritische benadering van het rechtsbewustzijn (legal consciousness). Deze benadering onderzoekt waarom mensen, ook al zijn zij ontevreden over het rechtssysteem, toch nog steeds veel verwachten van het recht. In zijn boek stelt hij voorop dat het overheidsrecht weliswaar steeds aanwezig maar niet altijd en overal zichtbaar is (p. 8). Hij kiest daarom een alternatieve seculiere benadering: hij onderzoekt waarom mensen zich afwenden van het recht (p. 12). Hij laat zich daarbij leiden door de gedachte dat de onvrede een geleidelijk en werelds proces in beweging zet van vervreemding met het recht (p. 14).

De eerste helft van het boek doet verslag van zijn literatuuronderzoek. De interne en externe cultuur van het recht moeten onderscheiden worden. De interne cultuur is die van juridische professionals, zoals rechters en advocaten; de externe is de cultuur die algemeen leeft onder de bevolking (p. 29). Het gaat er niet zozeer om of de Nederlanders in het rechtssysteem geloven, als wel of zij het nog wel begrijpen (p. 35). Er is niet zozeer sprake van vertrouwen in het recht, als wel van een pragmatische omgang ermee (p. 36). De legitimiteit van het rechtssysteem spreekt voor een aanzienlijk aantal mensen niet meer vanzelf (p. 41). De heersende Nederlandse rechtscultuur is er dan ook niet een van blind vertrouwen in rechtspraak en rechters, maar slechts van mokken en dulden van het overheidsrecht (sullen toleration, p. 43).

Waarom keren de mensen het recht de rug toe? Aan de hand van de literatuur ontwikkelt Hertogh een begrippenkader voor de beschrijving en analyse van het vervreemdingsproces in de praktijk. Met vervreemding wordt gedoeld op de kloof die wordt ervaren tussen intern en extern begrip van het recht. De band van gewone mensen met het overheidsrecht, inclusief het rechtssysteem, wordt losser en losser (p. 55). Onderscheiden worden gevoel en houding ten opzichte van het recht. Verhelderend - en zelfs onmisbaar om de tweede helft van het boek te kunnen begrijpen - zijn het spectrum van vervreemding en het diagram van profielen (p. 57 resp. p. 58). Dit spectrum betreft het gevoel van de mensen jegens het recht. Het heeft vier kleuren: betekenisloos, machteloos, cynisch en isolationistisch. De betekenislozen voelen zich niet in staat het recht te begrijpen en de uitkomst van procedures te voorspellen. De machtelozen hebben het gevoel dat ze geen grip meer hebben op deze uitkomst en dat zij bekneld zitten in het recht. De cynici vinden dat de regels van het rechtssysteem niet meer bindend zijn of 
zouden moeten zijn. De isolationisten, ten slotte, ervaren een onoverbrugbare afstand tussen de waarden van het recht en die van henzelf.

Het diagram van de profielen sluit hierop aan en betreft de houding van de mensen ten opzichte van het recht. Onderscheiden worden enerzijds bekendheid met het recht en anderzijds vereenzelviging met het recht. Wat het diagram betreft, kunnen de scores op deze twee onderdelen slechts negatief of positief zijn. Door deze twee onderdelen en de twee scores te combineren ontstaan vier profielen: legalisten, loyalisten, cynici en buitenstaanders. De legalisten zijn bekend met het recht en vereenzelvigen zich met het rechtssysteem. Loyalisten zijn daarentegen onbekend met het recht, maar vereenzelvigen zich toch met het rechtssysteem. Cynici zijn er wel bekend mee maar vereenzelvigen zich niet met het systeem en buitenstaanders weten het helemaal niet meer en staan met hun rug naar het overheidsrecht. Laat het spectrum en profiel even op u inwerken voordat $\mathrm{u}$ verder gaat met lezen. Mocht het $\mathrm{u}$ zijn gaan duizelen, dan doet $\mathrm{u}$ er het beste aan weer te beginnen bij de vorige alinea en dan het spectrum van vervreemding en het diagram van profielen allebei op papier uit te tekenen.

De tweede helft van het boek bevat drie case studies. Voor dit veldonderzoek zijn drie gevallen uitgekozen, waarin sprake is van vervreemding, niet bij gewone mensen maar juist bij juridische professionals. Het eerste geval betreft de reactie van de directeur van een openbare school op het negatieve oordeel van de Commissie gelijke behandeling (nu: College rechten van de mens) over de verplichting van (ook vrouwelijke) docenten om hun leerlingen - van beiderlei kunne - een hand te geven. Waar de commissie alleen kijkt naar het recht van de individuele docent op gelijke behandeling, heeft de directeur een veel breder doel voor ogen. Hij wil voorkomen dat de voornamelijk Turkse en Marokkaanse leerlingen later worden gediscrimineerd en wil hun daarom nu al op school vertrouwd maken met de omgangsvormen die in zijn ogen in Nederland gebruikelijk zijn (p. 98). Hertogh ziet in de reactie van de directeur niet alleen betekenis en machteloosheid, maar vooral ook cynisme en zelfs isolationisme (p. 100-102). De betrokkenen blijken geleidelijk meer afstand te zijn gaan nemen van de wetgeving inzake gelijke behandeling. Ook al is het een wet, het is gewoon niet echt van belang (p. 106).

Het tweede geval betreft de reacties van de grote aannemers tijdens de parlementaire enquête van 2002 naar de gang van zaken bij aanbesteding van infrastructurele bouwwerken door de overheid. Aan de aanbodzijde maakten grote aannemers in de weg- en waterbouw al voor de intekening onderling afspraken over de prijzen en de verdeling van de markt. Op de aanneemsom zat steeds een kop die onder de afvallers werd verdeeld. De Europese commissie had dit weliswaar al in 1992 verboden, maar de bedrijfstak ging ook daarna nog door met deze praktijken. Hertogh heeft kunnen putten uit de verslagen van de bouwenquête. Hij ziet onder de aannemers grote weerzin en weerstand: de overheid begrijpt de praktijk van de bouw niet; de nieuwe mededingingsregels zijn in het voordeel van de overheid die ook de grootste opdrachtgever is; deze praktijken zijn jarenlang door de vingers gezien; deze afspraken brengen niemand schade toe; er is geen echte markt vanwege het monopolie van de overheid aan de vraagzijde; de nieuwe 
mededingingsregels zijn oneerlijk omdat de prijzen daardoor kelderen (p. 112-114). Hertogh acht de meeste aannemers cynici en een aantal zelfs zeer isolationistisch. De meeste aannemers zien het geldende mededingingsrecht slechts als oneerlijke overheidsregels en zouden veel liever hun eigen eerlijke regels volgen, ook als die in strijd zijn met het recht (p. 127).

Het derde geval betreft de werkzaamheden van een interventieteam van gemeentelijke welzijnsambtenaren in een witte achterstandswijk in Zwolle. De bewoners van de Indische buurt hadden zich met hand en tand verzet tegen de toewijzing van een woning aan een zwart gezin. Het gemeentebestuur stelde vervolgens een team samen van een maatschappelijk werker, een politieman en iemand van de plaatselijke woningcorporatie. Dit interventieteam kreeg mandaat voor de toewijzing van woningen in de wijk, met voorbijgaan van huisvestingswetgeving. Het beleid van het team was dat de nieuwkomers moesten passen in de wijk en de wijk bij de nieuwkomers (p. 136). Enkele eerdere bladzijden zijn gewijd aan het begrip rechtsstaat. Hertogh gebruikt hier de Engelse term Rule of Law (heerschappij van het recht). Hij legt de nadruk op de elementen formele gelijkheid en wetmatigheid (legality). Het interventieteam streefde daarentegen naar materiële gelijkheid en responsiveness (p. 132: inlevend en snel reageren, aldus mijn Advanced Learner's Dictionary).

Hertogh stelt voorop dat het publieke recht met zijn ideaal van de rechtsstaat door het interventieteam werd ervaren als afstandelijk, van een andere wereld en niet legitiem (p. 133). In zijn streven naar materiële gelijkheid gebruikte het team huurcontracten om allerlei voorwaarden op te leggen. Daargelaten dat niet duidelijk wordt of de gemeente, de woningcorporatie of zelfs beiden de contracten hebben ondertekend, wekt Hertogh de indruk dat deze aanpak in strijd is met de huisvestigingswetgeving (p. 139). Daarna bevestigt hij met Rule of Law alleen de heerschappij van de wet en formele gelijkheid voor de wet op het oog te hebben. Aan publiekrecht ligt ten grondslag dat elke handeling van het bestuur op een wet moet zijn gebaseerd. Bovendien moeten alle wetten op alle mensen op gelijke wijze worden toegepast (p. 142). De meeste van de plaatselijke street-level bureaucraten zijn volgens hem cynici die zich machteloos voelen ten opzichte van het overheidsrecht en onder hen zijn ook buitenstaanders met een uitgesproken isolationistisch houding (p. 131 en p. 145).

Mijn voornaamste kritiek is dat in het boek een heldere afbakening ontbreekt van het object en het subject van de vervreemding van het recht. Is het object het oordeel van de Commissie gelijke behandeling of de rechtspraak in het algemeen? Het verbod van de Europese commissie of de hoorzittingen van de parlementaire enquêtecommissie in het bijzonder? De rechtsstaat in abstracto of de huisvestigingswetgeving in concreto? In dit verband is slechts een detail dat het gebruik van overeenkomsten naast vergunningen op grond van de tweewegenleer toelaatbaar kan zijn (ECLI:NL:HR:2012:BX0736). Van meer belang is dat Hertogh vervreemding niet ziet als een gegeven situatie maar als een proces. Naast de onderscheiden hoofdactoren zijn echter bij dit proces mijns inziens nog veel meer mensen betrokken. Is alleen de schooldirecteur het subject van vervreemding of 
ook zijn leraren, de leerlingen en hun ouders? Alleen de grote aannemers of ook hun personeel en de monopolistische opdrachtgever? Alleen het interventieteam of ook de wijkbewoners, het gemeentebestuur en de woningcorporatie?

Een kanttekening van geheel andere strekking is dat wetten en street-level bureaucraten niet altijd op voet van oorlog met elkaar verkeren. Er is veeleer sprake van een wisselwerking. Een mooi voorbeeld van bestuurlijke ongehoorzaamheid en het dynamische evenwicht tussen wetgeving en uitvoering is de Wet maatschappelijke ondersteuning (Wmo). De eerste wet uit 2006 voorzag in een sturing door middel van klassieke wettelijke normering met enige ruimte voor invulling door eigen decentrale beleidsregels. De rechter legde deze ruimte prompt aan strakke banden door de wettelijke compensatieplicht te benadrukken (ECLI:NL:CRVB:2008:BG6612). Daarop reageerde de VNG minstens even snel met haar gekantelde modelverordening van eind 2010 (van haar site verwijderd). Van de wettelijk verankerde aanspraken en aanbodgericht rechten stapten de gemeentelijke sociale diensten, mijns inziens in strijd met de wet, over op onderzoek naar de individuele behoeften en resultaatsgericht werken (SCP-publicatie 2013-31). Vervolgens codificeerde de wetgever deze kanteling in de nieuwe Wmo 2015 met haar keukentafelgesprekken en nog meer maatwerk. Dit werd door de rechter weer gecorrigeerd met behulp van de uit de rechtszekerheid voortvloeiende eis dat tenminste moet worden geïndiceerd op hoeveel uren huishoudelijk ondersteuning de cliënt recht heeft (ECLI:NL:CRVB:2018:3241). Met dit voorbeeld wil ik zeggen - en hier moet ik Hertogh bijvallen - dat vervreemding onder ons is. Niet alleen de gewone burger is vervreemd van de wet, maar ook de ambtenaar; niet alleen de kansarmen maar ook de (juridische) professionals, ja zelfs bestuurders, politici en belangenorganisaties. Dat doet overigens ook de vraag rijzen of misschien niet ook de wetgever zelf subject van vervreemding zou kunnen zijn, en dan zwijg ik maar over de rechterlijke macht (slechts - sic! - een beginselplicht tot handhaving; ECLI:NL:RVS:2013:455).

Het boek is een boeiend sociologisch onderzoek. Hertogh doet op bezonken en overtuigende wijze verslag van zijn gedegen onderzoek naar de hooibroei in de rechtsstaat: de groeiende vervreemding van het overheidsrecht onder de gehele bevolking, met inbegrip van juridische professionals. Hij is geslaagd in zijn opzet bij het onderzoek naar het rechtsbewustzijn de wissel om te zetten naar een geleidelijke en meer wereldse procesbenadering. Zijn literatuuronderzoek en selectie van de drie Nederlandse casussen zijn zeer de moeite van het lezen waard. Hetzelfde geldt voor het toefje room: het aanvullende onderzoek naar de bestuursrechtelijke afdoening van kleine overtredingen (p. 163). Dat de afbakening van object en subject van deze vervreemding scherper had kunnen zijn, doet niet af aan het belang en de betekenis van het boek. Een kniesoor die daar zwaar aan tilt. 